PROCEEDINGS OF THE WORLD CONFERENCE ON OZONE THERAPY IN MEDICINE, DENTISTRY AND VETERINARY. ANCONA (ITALY). SEPTEMBER 22nd - 23rd - 24th, 2017

\title{
Use of ozone in bone pathologies of the dog [abstract]
}

\section{Paolo Scrollavezza}

School of Biosciences and Veterinary Medicine, University of Camerino, Italy

\section{ABSTRACT}

\section{ठ OPEN ACCESS}

\section{Citation}

Scrollavezza P. Use of ozone in bone pathologies of the dog [abstract]. Proceedings of The World Conference on Ozone Therapy in Medicine, Dentistry and Veterinary. Ancona (Italy). September 22nd - 23rd - 24th , 2017. J Ozone Ther. 2019;3(4):57. doi 10.7203/jo3t.3.4.2019.15536

\section{Academic Editor}

Jose Baeza-Noci,

School of Medicine, Valencia

University, SPAIN

\section{Editor}

World Federation of Ozone Therapy, Bolgna, ITALY

\section{Received}

June 17, 2019

\section{Accepted}

December 08, 2019

Published

December 30, 2019

Intellectual Property

Paolo Scrollavezza.

This is an open access article distributed under the terms of the Creative Commons Attribution License (CC BY 4.0), which permits unrestricted use, distribution, and reproduction in any medium, provided the original author and source are credited.

\section{Author Information}

paolo.scrollavezza@gmail.com
The author presents his extended experiences using ozone to treat different orthopedic pathologies in the dog.

He illustrates the state of the art of how ozone can be useful as adjuvant or as a treatment in osteomyelitis and osteochondrosis, arthrosis and arthritis, malunion and nonunion fractures, open fractures, and spinal cord and vertebral disease.

In particular, numerous experiences will be described on the benefits of major ozone autohemotherapy (MAHT), minor ozone autohemotherapy (mAHT) and local ozone application in septic arthritis and open fractures; diseases in which antiseptic, healing and regenerative power of ozone seems more evident.

Author also describes his experiences about ozonized Acute Normovolemic Hemodilution $(\mathrm{OANH})$, an innovative technique to be used in synthesis of long bone fractures in the dog where significant blood loss is expected during orthopedic surgery.

\section{References}

1. Thakkar V, Thakkar $\mathrm{H}$. Ozone (O3): an excellent adjunctive tool in medical and surgical management of patient. Int $\mathrm{J}$ Res Med Sci. 2014;2:1257-1261.

2. Bocci V, Luzzi E, Corradeschi F, Paulesu L, Di Stefano A. Studies on the biological effects of ozone: III, an attempt to define conditions for optimal induction of cytokines. Lymp Cyt Res. 1993;12:121-126.

3. Nelemens PJ, deBie RA, deVet HC, Sturmans F. Injection therapy for subacute and chronic low back pain. Spine. 2001;26:501-515.

4. Kim HS, Noh SU, Han YW, Kim KM, Kang H, Kim HO, Park YM. Therapeutic effects of topical application of ozone on acute cutaneous wound healing. J Korean Med Sci. 2009;24:368-374.

5. Valacchi G, Fortino V, Bocci V. The dual action of ozone on the skin. $\mathrm{Br} \mathrm{J}$ Dermatol. 2005;153:1096-1100.

6. Shimizu N, Shimizu N. Ozone therapy for small animals. Journal of Traditional Veterinary Medicine. 2008. 